\title{
Testing Nordmøre grids on the target and by-catch species of the commercial bottom trawl fishery in the Gulf of Cadiz
}

\author{
MariÁngeles Gamaza ${ }^{1}$, Ignacio Sobrino ${ }^{1}$, Karim Erzini ${ }^{2}$ \\ ${ }^{1}$ IEO, Instituto Español de Oceanografía, Puerto pesquero, muelle de Levante s/n, 11006, Cádiz, Spain. \\ E-mail: mari.gamaza@gmail.com \\ ${ }^{2}$ Centre of Marine Sciences (CCMAR), University of Algarve, Campus de Gambelas, 8005-139 Faro, Portugal.
}

\begin{abstract}
Summary: Sorting grids have been tested worldwide in trawl fisheries. Here we report upon the first trials performed using Nordmøre sorting grids with four different bar spacings in the trawl fisheries of the Gulf of Cadiz targeting crustaceans as the main resource. A total of 288 valid hauls and 67 commercial species were caught. Escapement and escape size selectivity were evaluated for the most important target and by-catch species. A decrease in the percentage of biomass escape was recorded with increasing grid spacing for the two target species, deep-water rose shrimp (Parapenaeus longirostris) and Norway lobster (Nephrops norvegicus), from $24 \%$ to $8 \%$ for the former and from 86 to $9 \%$ for the latter, with a 15 -mm and 30-mm grid respectively. In general, high escape rates were found for most finfish and cephalopods. For hake (Merluccius merluccius), as the main by-catch species, the results showed an escape rate decreasing from $96 \%$ to $71 \%$ as the bar spacing increased. Our findings suggest the 30 -mm grid would be effective for the deep-water crustacean trawlers but different mitigation measures will be required for other métiers in the multispecies trawl fishery of the Gulf of Cadiz.
\end{abstract}

Keywords: by-catch; Gulf of Cadiz; deep-water rose shrimp; Nordmøre grids; selectivity; trawl fisheries.

Uso de rejillas separadoras Nordmøre sobre especies objetivo y accesorias de la flota de arrastre de fondo del Golfo de Cádiz

Resumen: Las rejillas o grillas separadoras han sido testadas en pesquerías de arrastre a nivel mundial. Aquí se exponen los resultados de los primeros ensayos usando rejillas separadoras tipo Nordmøre con cuatro espacios diferentes de separación entre barras para la flota de arrastre del Golfo de Cádiz que captura crustáceos como recurso principal. Se realizaron un total de 288 lances válidos y se capturaron unas 67 especies comerciales diferentes. El porcentaje de escape y la selectividad del escape por tallas fueron calculados para las especies comerciales y by-catch más importantes. Los resultados muestran un decrecimiento en el porcentaje de biomasa escapada al aumentar la separación entre barras para dos de las especies objetivos; gamba blanca (Parapenaeus longirostris) y cigala (Nephrops norvegicus), con porcentajes que oscilan desde 24 a $8 \%$ para la primera y 86 a $9 \%$ para la segunda, con las rejillas de $15 \mathrm{~mm}$ y $30 \mathrm{~mm}$ de separación entre barras respectivamente. En general, se obtienen altos porcentajes de escape para la mayoría de especies de peces y cefalópodos. Los resultados para merluza (Merluccius merluccius), como principal especie by-catch, muestran un decrecimiento en el porcentaje de escape desde $96 \%$ a $71 \%$ con el aumento de la separación entre barras respectivamente. Nuestros resultados sugieren que la rejilla de $30 \mathrm{~mm}$ de separación entre barras podría ser la más efectiva para la flota que dirige su captura a crustáceos en aguas profundas del Golfo de Cádiz pero diferentes medidas de mitigación serían necesarias para el resto de métiers de la pesquería de arrastre multiespecífica de esta zona.

Palabras clave: by-catch; Golfo de Cádiz; gamba blanca; rejilla Nordmøre; selectividad; pesquería de arrastre.

Citation/Como citar este artículo: Gamaza M.A., Sobrino I., Erzini K. 2015. Testing Nordmøre grids on the target and by-catch species of the commercial bottom trawl fishery in the Gulf of Cadiz. Sci. Mar. 79(4): 465-477. doi: http://dx.doi. org/10.3989/scimar.04180.15A

Editor: E. Massutí.

Received: November 17, 2014. Accepted: September 15, 2015. Published: October 16, 2015.

Copyright: () 2015 CSIC. This is an open-access article distributed under the Creative Commons Attribution-Non Commercial Lisence (by-nc) Spain 3.0. 


\section{INTRODUCTION}

The Gulf of Cadiz is located in the southern part of ICES Division IXa (Fig. 1). This region is considered a zone of exception where a minimum diamond-mesh codend size of $55 \mathrm{~mm}$ is allowed for the trawl fleet, whereas in the northern part of ICES Division IXa (Portugal) the minimum codend mesh size for fish is $70 \mathrm{~mm}$ and $55-59 \mathrm{~mm}$ is only allowed for shrimps.

Historically, the multispecies bottom trawl fisheries located in the Gulf of Cadiz exert a high fishing pressure on a large number of species. The fleet is currently composed of 142 vessels licensed to operate in the Gulf of Cadiz. The mean characteristics of this fleet are 25 GTR, $215 \mathrm{HP}$ and $13.9 \mathrm{~m}$ length, with average annual landings of around $12000 \mathrm{t}$.

The fishing grounds in the Gulf of Cadiz are characterized by a coastline of $300 \mathrm{~km}$ with a continental shelf more than $80 \mathrm{~km}$ wide. The western side of the platform is sandy and wider, becoming narrow and rocky near to the Strait of Gibraltar (Ramos et al. 1997). This different fishing grounds in which the trawling fleet operates, at depths of 20 to $600 \mathrm{~m}$, is reflected in the heterogeneity of the catches, with more than 70 different species landed (Sobrino et al. 1996). The composition of the landings depends on the target species, vessel characteristics, the distance of fishing ground from the landing port, the season of the year and the fishing strategy of the skipper. In coastal grounds target species include flatfish such as wedge sole (Dicologlossa cuneata (Linnaeus, 1758)), sole (Solea spp. (Linnaeus, 1758)), spotted flounder (Citharus linguatula (Linnaeus,
1758)), cephalopods such as cuttlefish (Sepia officinalis (Linnaeus, 1758)), octopus (Octopus vulgaris (Cuvier, 1797)) and squid (Loligo vulgaris (Lamarck, 1798)), and crustaceans such as caramote prawn (Melicertus kerathurus (Forskal, 1771)).

At deeper grounds target species are deep-water rose shrimp $((P$. longirostris (Lucas, 1846)), Norway lobster (Nephrops novergicus (Linnaeus, 1750)), horse mackerel (Trachurus trachurus (Linnaeus, 1758)), and blue whiting (Micromesistius potassou (Risso, 1827)). European hake (Merluccius merluccius (Linnaeus, 1758)) can be found at different depths depending on their growth and biological cycle, with smaller individuals found in shallower waters, whereas mature and larger hake inhabit greater depths (González et al. 1994).

In this scenario the local trawl fleet working in this area has changed its modus operandi over the years and is now composed of different métiers, with a division of the fleet by fishing grounds (Jiménez et al. 2004) and some of the vessels fishing solely for crustaceans, targeting deep-water rose shrimp and Norway lobster as the main resources. The deep-water rose shrimp fishery is the largest one in this area, with annual landings of 300 to $1000 \mathrm{t}$ of this high-value target species (Sobrino et al. 1994, Sobrino and García 2007).

The poor selectivity resulting from the use of the current 55-mm diamond-mesh codend used for all depths and grounds contributes to catches consisting of a large number of species with no commercial value, and of commercial individuals smaller than the minimum legal size.
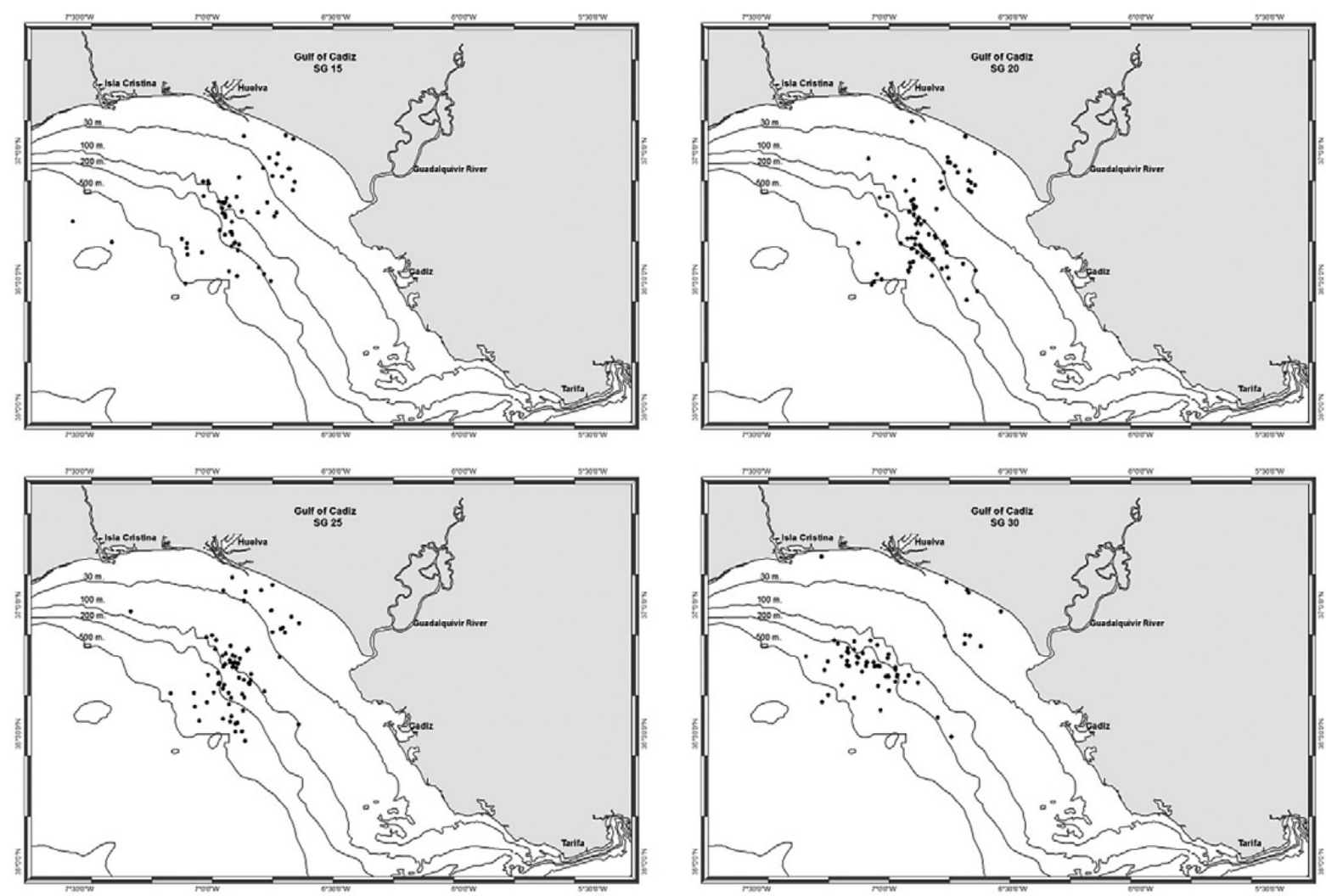

Fig. 1. - Spacial distribution of the sampling by sorting grid in the Gulf of Cadiz. 


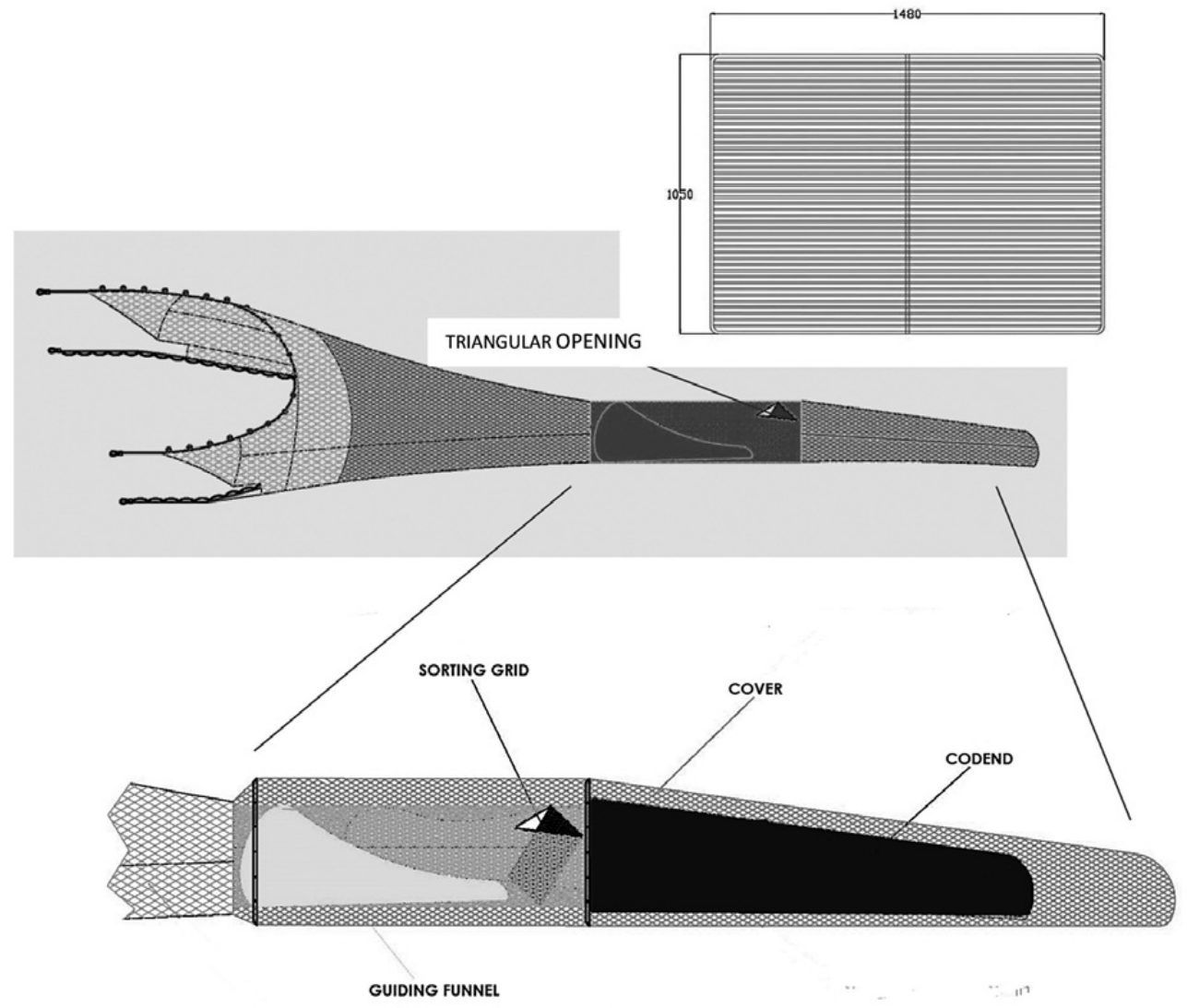

Fig. 2. - Technical drawing of the Nordmøre grid used in the experimental trials.

Much of this by-catch is not marketed or used and the unwanted animals are discarded and thrown back into the sea. The latest studies on trawl discards in the area show percentages ranging from $17 \%$ to $47 \%$ depending on the time of the year and depth range (Coll et al. 2014).

The demersal resources of the Gulf of Cadiz are considered to be overexploited, with depleted stocks and expansion of fishing activities towards deeper and more distant fishing grounds (Coll et al. 2014). The need for solutions and management measures, when landings are reaching their historical minimum, is highlighted by the concerns of the local fishing industry, skippers and vessel owners.

Some countries with similar multispecies trawl fisheries but exploiting shrimp or prawn resources have implemented selective devices in their trawl fleets, commonly referred to as by-catch reduction devices. Based on the behavioural differences between fish and crustacean species when encountering a sorting grid device (Isaksen 1990, Fonseca et al. 2005), these selective devices have proven successful at reducing unwanted by-catch without excessive loss of target species (Isaksen 1990, Isaksen et al. 1992, Broadhurst 2000, Ercoli et al. 2001).

The reformed EU Common Fisheries Policy (EU Regulation 1380/2013) considers the problem of discards a top priority, stipulating a progressive phasing out of discards ('landing obligation') of commercial species subject to quotas or minimum conservation reference sizes. Exceptions are allowed for species for which high survival after discarding has been proven.

Target species and species compositions of the catches in the Gulf of Cadiz trawl fishery vary considerably with depths, suggesting that different mitigation measures will be required in this multispecies trawl fishery for the different trawl métiers.

This study was undertaken to test the performance of the different sorting grids (with a bar spacing of $15,20,25$ and $30 \mathrm{~mm}$ ) under commercial conditions in the trawl fleet targeting crustaceans in the Gulf of Cadiz. In order to check whether their future use would be practical in the analysed fishery, two aspects were taking into account: the potential reduction of the bycatch and discarded species and the potential losses of the target crustacean species. Furthermore, the quality of the crustacean catches is considered as a key point for the acceptance of the device by the fishermen and its future use. Future introduction of mitigation measures for the vessels operating with this device will be recommended.

\section{METHODS}

The sorting grid tested in this study was made of stainless steel with an inclined rectangular $(1480 \mathrm{~mm}$ high $x 1050 \mathrm{~mm}$ wide) design originating from Norway (Valdermasen et al. 1993). Four different bar spacings $(15,20,25$ and $30 \mathrm{~mm}$ ) were tested (Fig. 2).

The rigging angle of the grid was set to $45^{\circ}$, since it has been demonstrated in previous studies that this is the best working angle for this design (Isaksen et al. 1992), 
Table 1. - Mean characteristics of the vessels used in this study.

\begin{tabular}{lcccc}
\hline Vessel name & Grid $(\mathrm{mm})$ & GRT & Length $(\mathrm{m})$ & $\mathrm{Hp}$ \\
\hline Nuevo capricho & 15 & 46.75 & 17.05 & 190 \\
Juan Prim & 20 & 73.05 & 19.50 & 250 \\
Nvo Carmen M. & 25 & 49.00 & 18.20 & 268 \\
Isabel y Paco & 30 & 68.07 & 24.20 & 250 \\
\hline
\end{tabular}

and a guiding funnel was installed in front of the grid to avoid shrimp losses. When large individuals come into contact with the grid, they can escape through a triangular opening at the top of the codend. Smaller species and individuals can pass through the grid and enter the 20-mm mesh codend. Selectivity of sorting grids was assessed using a 20-mm mesh cover, following the specifications of Wileman et al. (1996), placed above the triangular opening to catch individuals that escaped through the triangular opening above the grid (Fig. 2).

The selectivity study was carried out from 15 July to 10 September 2008 (40 days at sea), on-board four chartered fishing vessels of similar technical characteristics (Table 1) operating their own commercial trawls and fishing according to normal commercial trawling practices. The trawl used by the vessels under study is constructed of polyamide netting with a $20-\mathrm{mm}$ diamond-mesh codend. Each vessel used a sorting grid with one type of bar spacing $(15,20,25$ or $30 \mathrm{~mm})$. Tows were carried out at depths ranging from 20 to $550 \mathrm{~m}$, covering the bathymetric range of the deepwater rose shrimp (Sobrino 1998) in the Gulf of Cadiz area (Fig. 1). A total of 288 valid hauls were made under commercial towing conditions (Fig. 1, Table 2). Towing speeds varied between 2.5 and 3.5 knots, whereas tow duration ranged from 2 to more than 7 hours, depending on depth and area, with generally longer tows with increasing depth.

The catches in the codend and cover of each haul were sorted by species, counted and weighed. For the most important commercial finfish species, total length (TL) was rounded down to the centimetre below. For commercial crustaceans, carapace length (CL) was rounded down to the millimetre below. For cephalopods, the mantle length (ML) was rounded down to the centimetre below. Sub-sampling of the rest of the bycatch species was carried out with TL rounded down to the centimetre below.

For the main commercial species, the cover and codend catches were analysed to assess the effectiveness of different grids. Target species considered were deep-water rose shrimp with a minimum landing size (MLS) of $22 \mathrm{~mm} \mathrm{CL}$, caramote prawn with no MLS in the area and Norway lobster with an MLS of $20 \mathrm{~mm}$ CL. Commercial by-catch species considered in this study include hake, with a 27-cm TL MLS, spotted flounder, cuttlefish and squid, the last three with no MLS in the Gulf of Cadiz.

Although the grids are designed to exclude by-catch fish species without losing much of the crustacean target species catch, they introduce size-selective effects on the target crustaceans. Therefore, the KolmogorovSmirnov (K-S) test was used to compare the size distributions of catches retained in the codend and the cover for the sorting grids with different bar spacings. The influence of depth and tow duration on escapement was evaluated by two-way ANOVA.

Size selectivity was modelled with three models: the generalized logistic model, the asymmetric Richards model and a model incorporating encounter probability. The generalized logistic model is

$$
r l=\frac{e^{(a+b l)}}{1+e^{(a+b l)}}
$$

where $r l$ is the probability that fish of length $l$ will be retained in the cover (i.e. will escape through the triangular opening), and $a$ and $b$ are the parameters to estimate. Length at which the probability of being retained is $50 \%\left(\mathrm{~L}_{50}\right.$, length at first capture) and selection range (SR: $\mathrm{L}_{75}-\mathrm{L}_{25}$ ) were calculated from the expressions:

$$
L_{50}=-\frac{a}{b} \quad S R=\frac{L_{n}(9)}{b}
$$

The Richards asymmetric model (Wileman et al. 1996) is

$$
r l=\left(\frac{e^{(a+b l)}}{1+e^{(a+b l)}}\right)^{1 / \delta}
$$

where $\delta$ is the asymmetric parameter. If $\delta=1$, it will be equivalent to the logistic model; if $\delta>1$, the curve has a longer tail to the left; and if $0<\delta<1$, it has a longer tail to the right end.

To account for possible active avoidance behaviour of some fish and cephalopods, an encounter probability model (Tokai 1996) was also fitted:

$$
r l=\frac{p^{*} e^{(a+b l)}}{\left[1+e^{(a+b l)}\right]+[1-p]}
$$

where $p$ is the contact probability with the grids, and $a$ and $b$ are parameters of the logistic model.

The estimation of selectivity parameters $a, b, \delta$ and $\mathrm{p}$ was carried out by maximizing the log-likelihood using an Excel $^{\mathrm{TM}}$ Solver and a spreadsheet provided by Professor Tadashi Tokai (1997) of the University of Tokyo. The model with the lowest Akaike information criterion (Akaike 1974) was chosen as the one that best fitted the data.

Table 2. - Number of valid hauls and weight percentage by grid (bar spacing) and bathymetric stratum.

\begin{tabular}{lcccccccccc}
\hline & \multicolumn{2}{c}{ 10-100 } & \multicolumn{2}{c}{ 100-200 } & \multicolumn{2}{c}{ Depth range (m) } & \multicolumn{3}{c}{ 200-300 } & \multicolumn{2}{c}{ 300-500 } & \multicolumn{2}{c}{ Total } \\
Bar spacing (mm) & hauls & weight $\%$ & hauls & weight $\%$ & hauls & weight $\%$ & hauls & weight \% & hauls & weight \% \\
\hline 15 & 24 & 12 & 16 & 16 & 8 & 35 & 12 & 22 & 60 & 18 \\
20 & 43 & 50 & 29 & 31 & 4 & 27 & 14 & 26 & 90 & 32 \\
25 & 27 & 36 & 23 & 34 & 7 & 29 & 18 & 29 & 75 & 33 \\
30 & 11 & 2 & 23 & 19 & 13 & 9 & 16 & 23 & 63 & 17 \\
Total & 105 & 100 & 91 & 100 & 32 & 100 & 60 & 100 & 288 & 100 \\
\hline
\end{tabular}




\section{RESULTS}

\section{Catch data}

A total of 67 commercial species were caught (52 finfishes, 5 crustaceans and 10 cephalopods) (Table 3 ). The most important fish species was hake, which accounted for $28.2 \%$ of the total fish catch. The second most important was blue whiting, which accounted for $21.3 \%$. Other important species were spotted flounder and Atlantic horse mackerel, which accounted for less than $10 \%$ each. For crustaceans, deep-water rose shrimp was the most important species caught, accounting for $80.1 \%$ of the crustacean catch in weight. Other important species were Norway lobster and prawn. Of the cephalopods, octopus, cuttlefish and squid accounted for $32.2 \%, 17.5 \%$ and $11.9 \%$ of the total cephalopod catch, respectively.

Figure 3 shows mean yields $\left(\mathrm{kg} \mathrm{h}^{-1}\right)$ for total retained and escaped catch by sorting grid and depth strata. The catches showed clear differences between sorting grids and depths. For all four grids the lowest yields corresponded to deeper stratum, whereas the highest ones corresponded to shallower strata. Retained catch yields ranged from $7.4 \mathrm{~kg} \mathrm{~h}^{-1}$ in the $\mathrm{C}$ stratum to $33.2 \mathrm{~kg} \mathrm{~h}^{-1}$ in the B stratum. Escaped catch ranged from $11.6 \mathrm{~kg} \mathrm{~h}^{-1}$ to $44 \mathrm{~kg} \mathrm{~h}^{-1}$ in the $\mathrm{C}$ and $\mathrm{A}$ strata, respectively.

The escape percentages for each type of grid against the tow duration and depth are given in Figure 4. As expected, escape percentages decreased with increasing grid spacing, but the effects of tow duration and depth differed between grids. While the interaction between depth and tow duration (two-way ANOVA) was not significant for any grid ( $>0.05)$, depth was a significant factor for the 15- and 25-mm sorting grids $(\mathrm{p}<0.05)$ and tow duration was significant $(\mathrm{p}=0.024)$ only for the 20 -mm sorting grid.

The percentages of escaped (cover) and retained (codend) biomass for 3 crustacean, 4 fish and 3 cephalopod species are given in Figure 5. As the space between the bars increases, so does the percentage of retained biomass of deep-water rose shrimp (76\%-92\%), prawn $(23 \%-86 \%)$, and Norway lobster (14\%-91\%) (Fig. 5A,C).

For the commercial by-catch species under analysis, the sorting grids permitted a significant escape percentage among finfish species: $96 \%-71 \%$ for hake, $65 \%$ $27 \%$ for spotted flounder, 93\%-63\% for blue whiting and $94 \%-77 \%$ for Atlantic horse mackerel (Fig. 5D,G). The same tendency is observed for cephalopod species: $81 \%-39 \%$ for squid as the spacing between the bars increased, 95\%-69\% for cuttlefish and 78\%-68\% for octopus (Fig. 5H,J).

At first sight, the grid with $30 \mathrm{~mm}$ between the bars is the one that achieves the highest catch percentage for the crustaceans, with an average of $60 \%$ less finfish and cephalopods retained in the codend, so it is the one that best achieves the sorting objectives of the device (Fig. 5A,J).
Table 3. - Total catches in weight $(\mathrm{kg})$, number and weight percentage of commercial species of fishes, crustaceans and cephalopods during the survey.

\begin{tabular}{|c|c|c|c|}
\hline FISHES & Weight & Number & $\%$ Weight \\
\hline Merluccius merluccius & 4057 & 34161 & 28.19 \\
\hline Micromesistius poutassou & 3066 & 25926 & 21.31 \\
\hline Scomber scombrus & 1260 & 11055 & 8.76 \\
\hline Scomber japonicus & 1086 & 8237 & 7.55 \\
\hline Citharus linguatula & 1075 & 36453 & 7.47 \\
\hline Trachurus trachurus & 607 & 9795 & 4.22 \\
\hline Mullus surmuletus & 503 & 22339 & 3.50 \\
\hline Engraulis encrasicolus & 393 & 18578 & 2.74 \\
\hline Diplodus sargus sargus & 280 & 909 & 1.95 \\
\hline Trachurus mediterraneus & 271 & 3059 & 1.89 \\
\hline Pagellus erythrinus & 229 & 2770 & 1.59 \\
\hline Sardina pilchardus & 205 & 3729 & 1.43 \\
\hline Trachinus draco & 202 & 2807 & 1.41 \\
\hline Microchirus azevia & 105 & 1756 & 0.73 \\
\hline Lophius budegassa & 97 & 17 & 0.68 \\
\hline Trachurus picturatus & 91 & 523 & 0.63 \\
\hline Scyliorhinus canicula & 88 & 238 & 0.61 \\
\hline Dicologoglossa cuneata & 81 & 2287 & 0.56 \\
\hline Pagellus bellotii & 73 & 833 & 0.51 \\
\hline Balistes carolinensis & 69 & 84 & 0.48 \\
\hline Pagellus acarne & 53 & 572 & 0.37 \\
\hline Diplodus bellottii & 52 & 1000 & 0.36 \\
\hline Galeus melastomus & 49 & 103 & 0.34 \\
\hline Lithognathus mormyrus & 46 & 151 & 0.32 \\
\hline Sparus aurata & 46 & 74 & 0.32 \\
\hline Phycis blennoides & 41 & 173 & 0.28 \\
\hline Liza aurata & 30 & 81 & 0.21 \\
\hline Solea solea & 30 & 150 & 0.21 \\
\hline Cepola macrophthalma & 29 & 381 & 0.20 \\
\hline Diplodus annularis & 29 & 724 & 0.20 \\
\hline Solea senegalensis & 25 & 90 & 0.18 \\
\hline Pomadasys incisus & 23 & 155 & 0.16 \\
\hline Helicolenus dactylopterus & 19 & 75 & 0.13 \\
\hline Lophius piscatorius & 18 & 5 & 0.12 \\
\hline Centroscymnus coelolepis & 15 & 42 & 0.11 \\
\hline Dentex canariensis & 16 & 42 & 0.11 \\
\hline Spondyliosoma cantharus & 4 & 27 & 0.03 \\
\hline Synaptura lusitanica & 5 & 34 & 0.03 \\
\hline Argyrosomus regius & 3 & 21 & 0.02 \\
\hline Raja montagui & 3 & 2 & 0.02 \\
\hline Solea kleinii & 2 & 18 & 0.02 \\
\hline Brama brama & 1 & 1 & 0.01 \\
\hline Macroramphosus scolopax & 1 & 9 & 0.01 \\
\hline Pagellus bogaraveo & 2 & 12 & 0.01 \\
\hline Psetta maxima maxima & 1 & 2 & 0.01 \\
\hline Raja asterias & 1 & 1 & 0.01 \\
\hline Spicara flexuosa & 2 & 4 & 0.01 \\
\hline Dentex gibbosus & 0 & 1 & 0.00 \\
\hline Dicentrarchus labrax & 0 & 2 & 0.00 \\
\hline Diplodus vulgaris & 0 & 1 & 0.00 \\
\hline Mullus barbatus & 1 & 12 & 0.00 \\
\hline Umbrina ronchus & 1 & 2 & 0.00 \\
\hline Total fishes & 14390 & 189523 & 100 \\
\hline \multicolumn{4}{|l|}{ CRUSTACEANS } \\
\hline Parapenaeus longirostris & 10232 & 1515315 & 80.1 \\
\hline Nephrops norvegicus & 2073 & 88485 & 16.2 \\
\hline Squilla mantis & 400 & 12101 & 3.1 \\
\hline Penaeus kerathurus & 69 & 1956 & 0.5 \\
\hline Palinurus elephas & 3 & 4 & 0.0 \\
\hline Total crustaceans & 12776 & 1617861 & 100 \\
\hline \multicolumn{4}{|l|}{ CEPHALOPODS } \\
\hline Octopus vulgaris & 1486 & 4912 & 32.2 \\
\hline Eledone moschata & 1299 & 6259 & 28.2 \\
\hline Sepia officinalis & 571 & 2841 & 12.4 \\
\hline Loligo vulgaris & 342 & 5779 & 7.4 \\
\hline Sepia elegans & $27 \overline{5}$ & 27775 & 6.0 \\
\hline Alloteuthis media & 241 & 48497 & 5.2 \\
\hline Eledone cirrhosa & 217 & 682 & 4.7 \\
\hline Illex coindetii & 176 & 963 & 3.8 \\
\hline Sepia orbignyana & 1 & 12 & 0.0 \\
\hline Todarodes sagittatus & 1 & 2 & 0.0 \\
\hline Total cephalopods & 4609.3 & 97722 & 100 \\
\hline
\end{tabular}



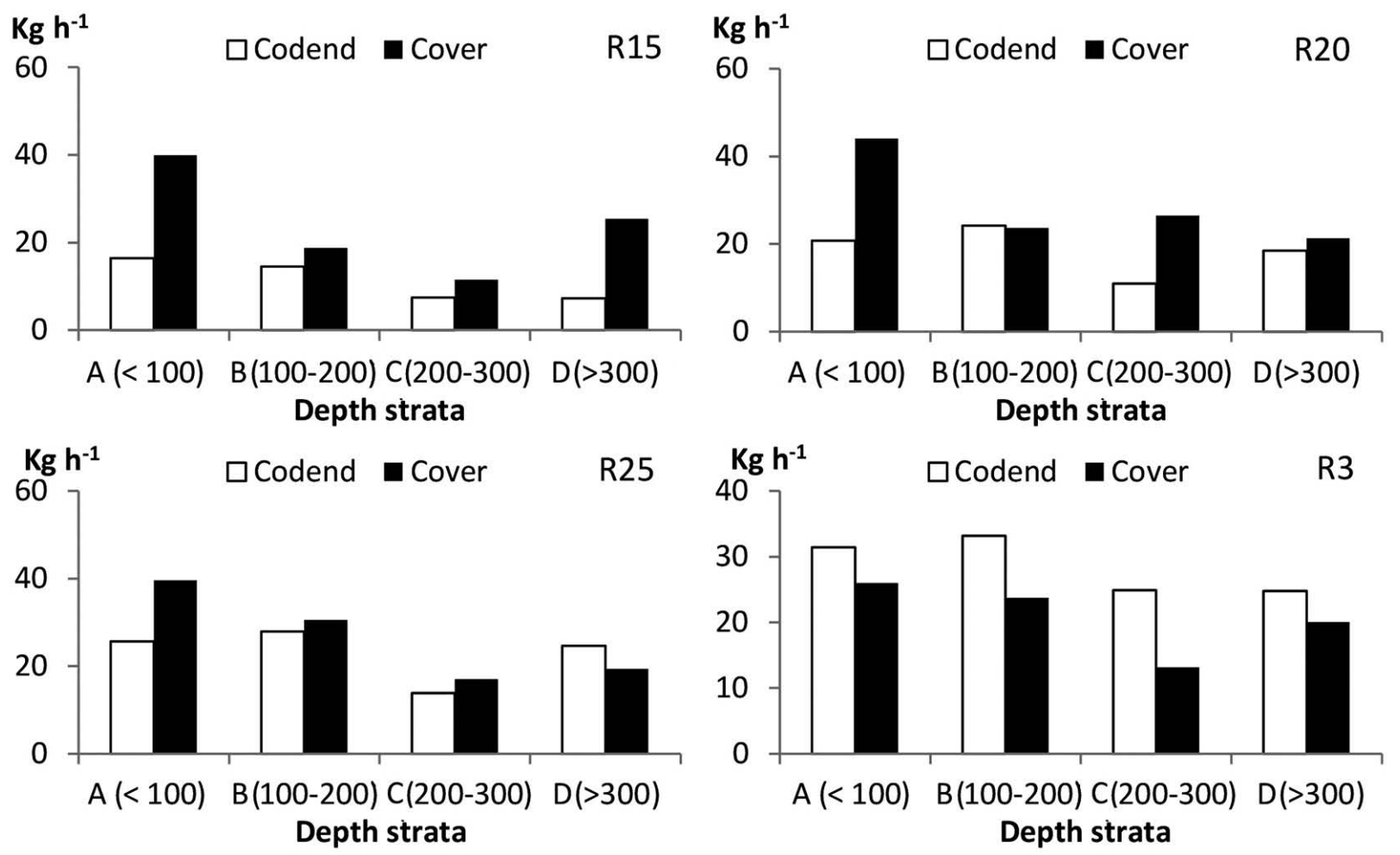

Fig. 3. - Mean yield $\left(\mathrm{kg} \mathrm{h}^{-1}\right)$ for the total retained catch (codend) and escaped catch (cover) by depth and sorting grid.

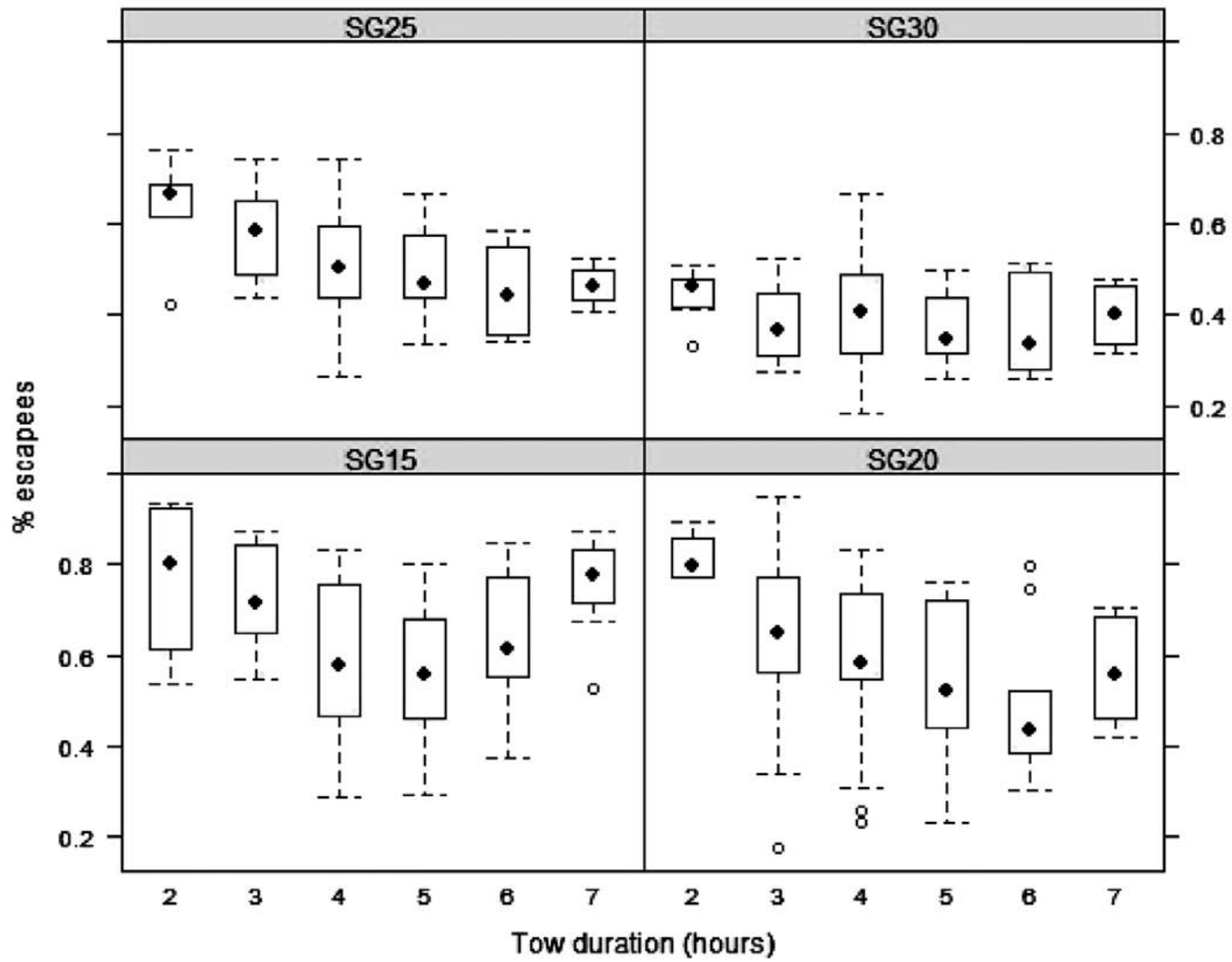

Fig. 4. - Percentage of escaped individuals and tow durations for each sorting grid (SG 15 SG 20, SG 25 and SG 30 corresponding to 15-, 20-, 25- and, 30-mm bar spacing, respectively). 


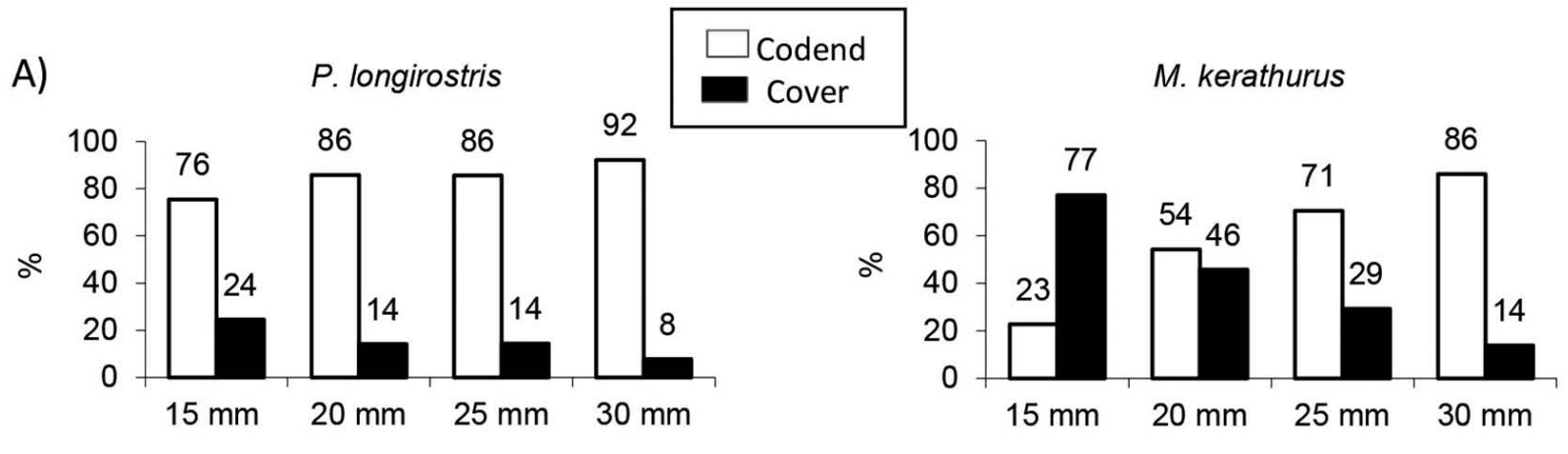

C)

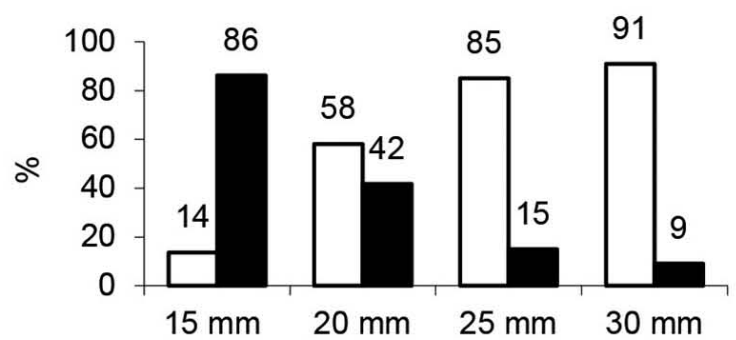

E)

C. linguatula

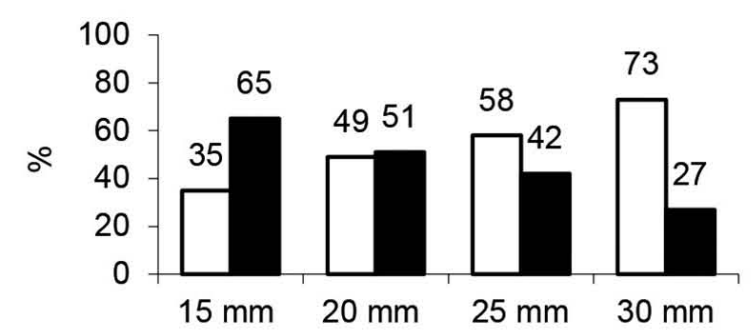

G)

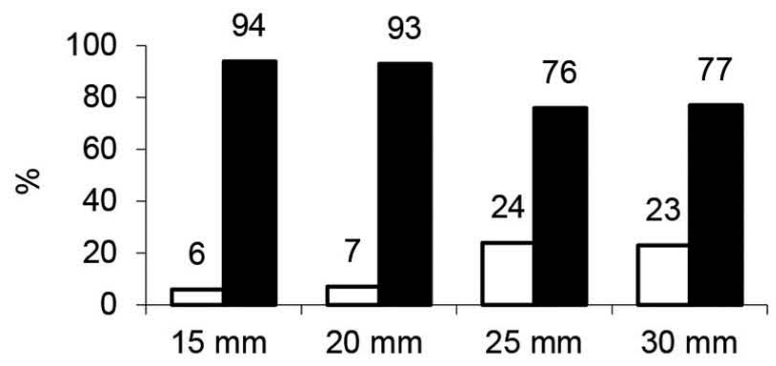

I)

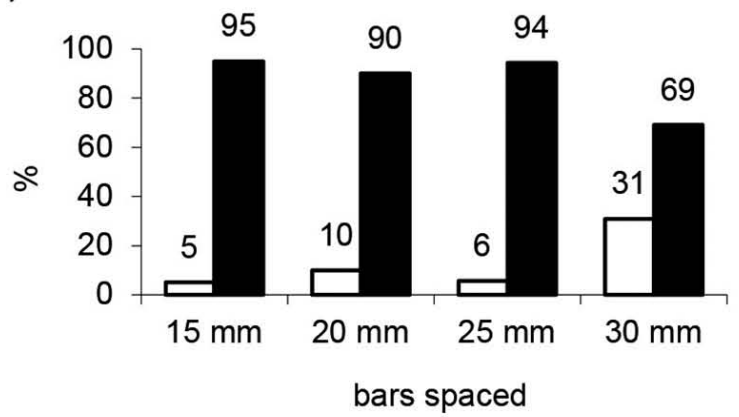

D)

M. merluccius

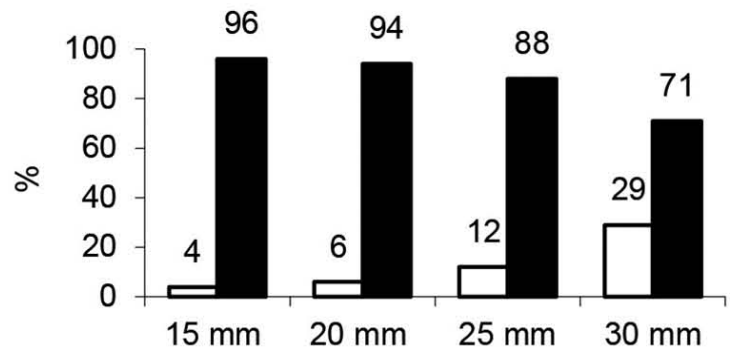

F)

M. poutassou

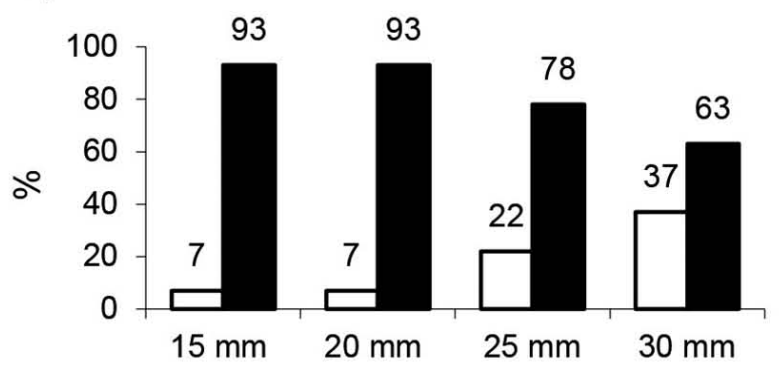

H)

L.vulgaris

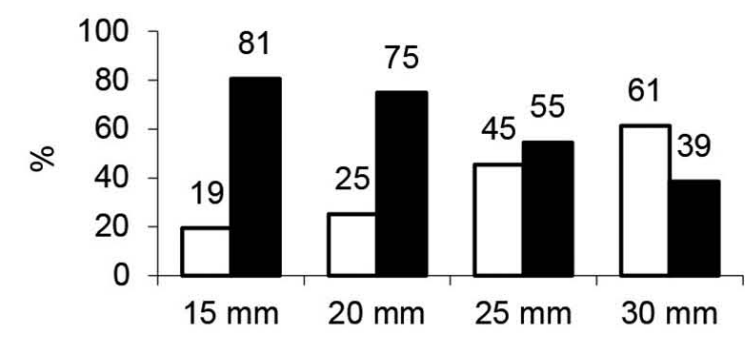

J)

O. vulgaris

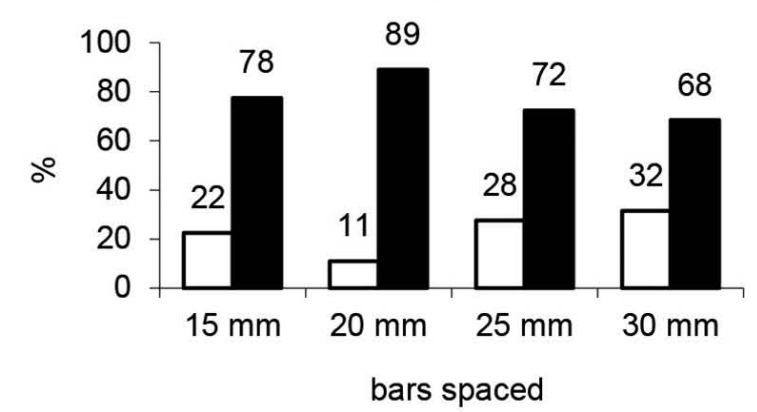

Fig. 5. - Percentage of biomass caught in the cover and in the codend by grid for the target and some by-catch species. 

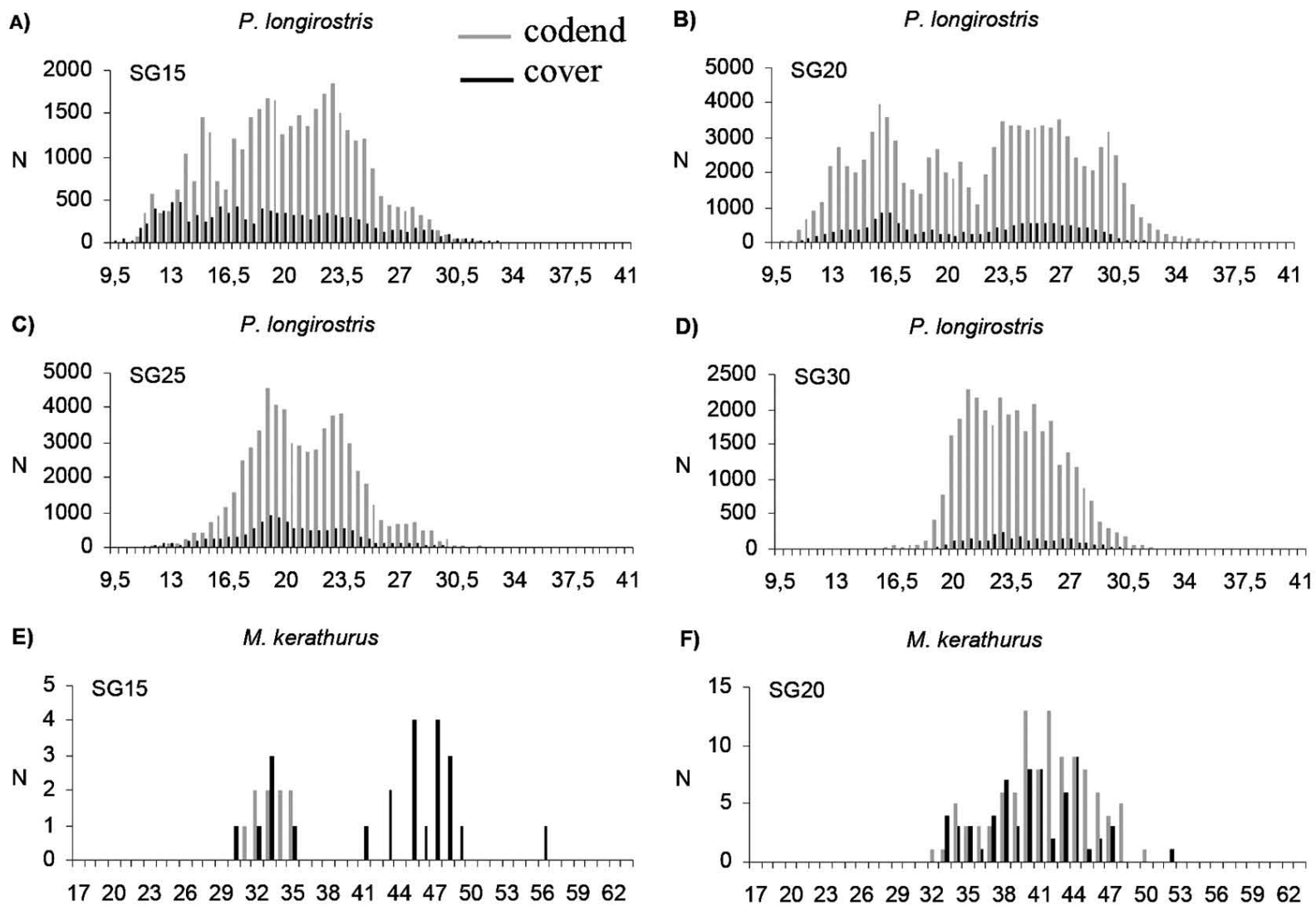

F)

M. kerathurus

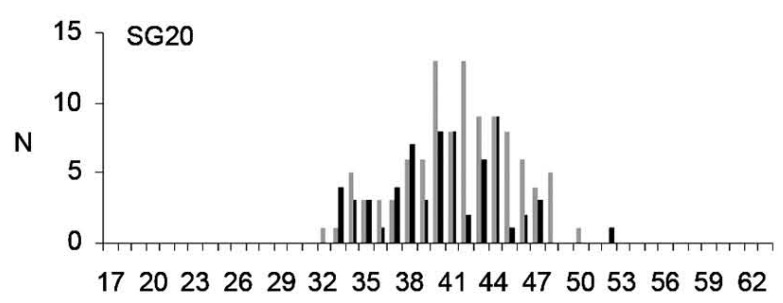

G)

M. kerathurus

H)

M. kerathurus

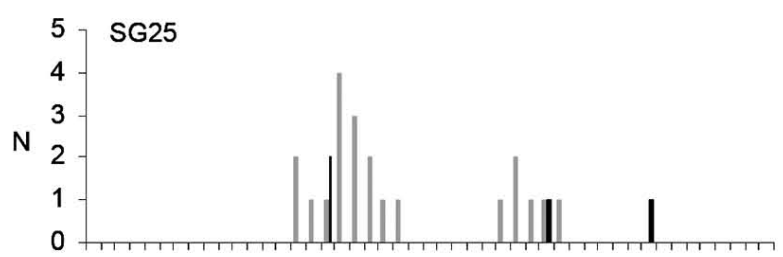

$\begin{array}{llllllllllllllll}17 & 20 & 23 & 26 & 29 & 32 & 35 & 38 & 41 & 44 & 47 & 50 & 53 & 56 & 59 & 62\end{array}$

I)

N. norvegicus

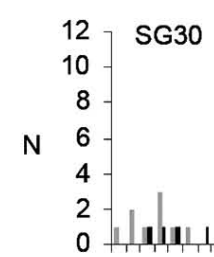

G30

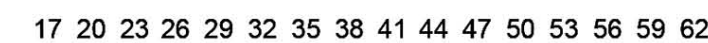

J)

N. norvegicus
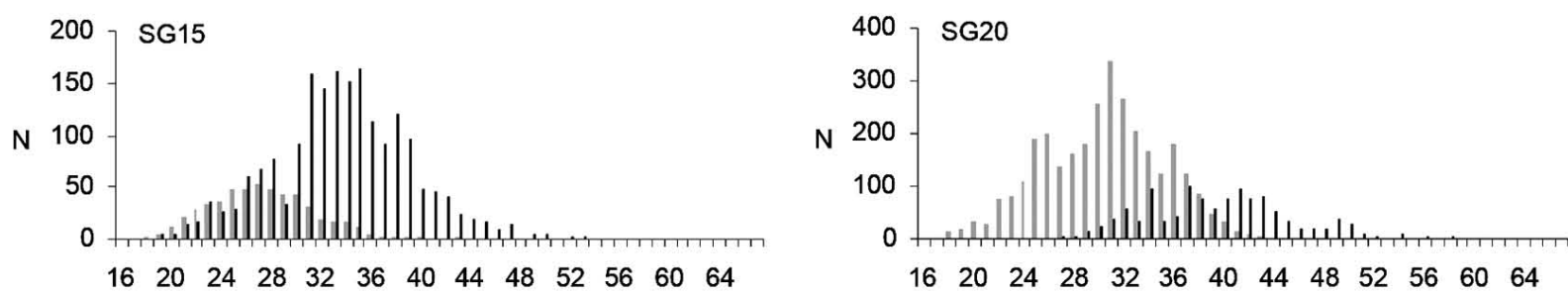

K)

N. norvegicus

L)

N. norvegicus
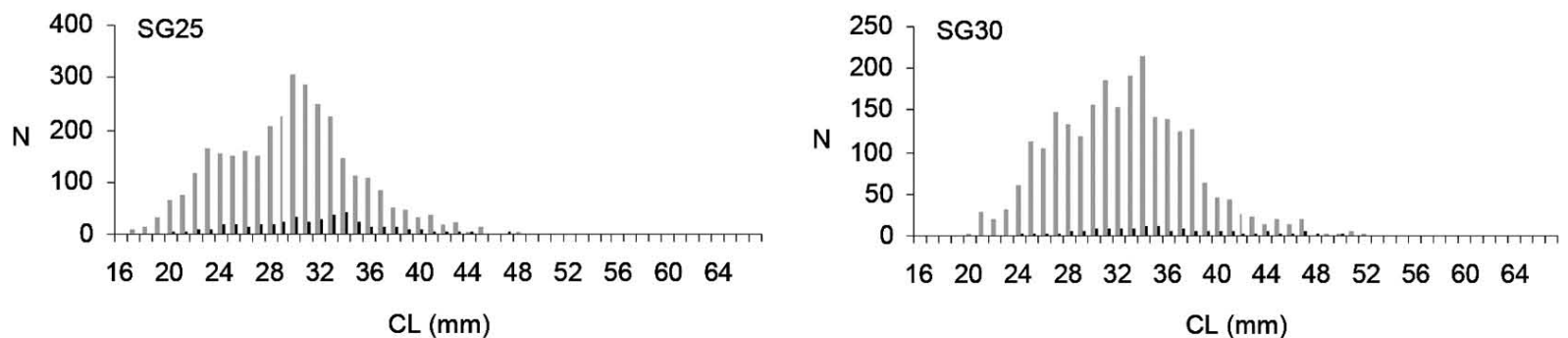

Fig. 6. - Cover and codend length distributions of P. longirostris (A-D for 15- to 30-mm bar spacing, respectively), M. kerathurus (E-F for 15- to 30-mm bar spacing, respectively), and $N$. norvegicus (G-L for 15- to 30-mm bar spacing, respectively). 
Table 4. - Results of the Kolmogorov-Smirnov test ( $\alpha=0.01$; NS not significant) comparing cover and codend length-frequency distributions.

\begin{tabular}{lcccc}
\hline & \multicolumn{4}{c}{ Bar spacing } \\
Species & $15 \mathrm{~mm}$ & $20 \mathrm{~mm}$ & $25 \mathrm{~mm}$ & $30 \mathrm{~mm}$ \\
\hline P. longirostris & $\alpha$ & $\alpha$ & $\alpha$ & $\alpha$ \\
M. kerathurus & $\alpha$ & $\alpha$ & $\alpha$ & $\alpha$ \\
N. norvegicus & $\alpha$ & $\alpha$ & $\alpha$ & $\alpha$ \\
C. linguatula & $\alpha$ & $\alpha$ & $\alpha$ & $\mathrm{NS}$ \\
M. merluccius & $\alpha$ & $\alpha$ & $\alpha$ & $\alpha$ \\
L. vulgaris & $\alpha$ & $\alpha$ & $\alpha$ & $\alpha$ \\
S. officinalis & $\mathrm{NS}$ & $\alpha$ & $\alpha$ & $\alpha$ \\
\hline
\end{tabular}

\section{Target species}

Length-frequency distributions for the crustacean species are given in Figure 6. For deep-water rose shrimp the size range varied from 10 to $40 \mathrm{~mm} \mathrm{CL}$ (Fig. 6A,D). Significant differences were found between codend and cover size distributions, according to the K-S test (Table 4). However, selectivity parameters could not be estimated for this species due to lack of convergence, probably due to the lack of selectivity, with very similar size ranges for the codend and the cover for deep-water rose shrimp.

The same results were found for the caramote prawn. The size range varied from 17 to $63 \mathrm{~mm} \mathrm{CL}$ (Fig. 6A,D), with significant differences between codend and cover distributions but selectivity parameters could not be estimated due to lack of convergence.

The size range of Norway lobster caught varied between 16 and $60 \mathrm{~mm} \mathrm{CL}$ (Fig. 6I,L), with significantly different codend and cover distributions according to the K-S test (Table 4). It was possible to estimate selectivity parameters for the 15 - and $20-\mathrm{mm}$ grids but not for the 25- and 30-mm grids due to the low escapement percentages and overlapped cover and codend distributions (Fig. 7). The $\mathrm{L}_{50}$ value for the $15-\mathrm{mm}$ grid was $30.31 \mathrm{~mm} \mathrm{CL}$, while for the $20 \mathrm{~mm}$ grid $\mathrm{L}_{50}$ it was $34.73 \mathrm{~mm}$ CL (Table 5). In both cases, individuals were retained above the legal MLS of $20 \mathrm{~mm}$ CL for Norway lobster in the Gulf of Cadiz (Spanish Royal Decree 560/1955 dated April 7, 1995 establishing minimum legal sizes for certain fished species). Compared with the $15-\mathrm{mm}$ grid, the $20-\mathrm{mm}$ grid increased the percentage of retained Norway lobster (Fig. 5C), without reaching the percentages caught with the 25and $30-\mathrm{mm}$ grids, for which there was relatively little escapement.

\section{By-catch species}

Hake from 7 to $60 \mathrm{~cm}$, with modes between 11 and $15 \mathrm{~cm}$ TL depending on the bar spacing, were caught. According to the K-S test (Table 4), codend and cover size distributions were significantly different, showing that for this species the by-catch reduction device was highly size-selective. The sorting grids retained sizes between 7 and $29 \mathrm{~cm}$ TL, below the MLS for hake (although with low percentages, Fig. 5D), while allowing the larger sizes to escape. The estimated $\mathrm{L}_{50}$ values were $14.27,19.10,23.58$ and $28.17 \mathrm{~cm}$ for the 15,20 , 25 and $30 \mathrm{~mm}$ grids, respectively (Table 5 and 6).

For spotted flounder, size distributions of the codend and cover were significantly different for all sorting grids except for the 30 -mm grid (Table 4). Selectivity estimates could only be estimated for the 15- and 20-mm grids, with estimates of $\mathrm{L}_{50}$ of 14.87 and 16.68 $\mathrm{cm}$ TL, respectively (Table 5). The catch percentage

Table 5. - Escape selection curve parameters (a, b, $\delta$ and p), length of $50 \%$ escapement $\left(\mathrm{L}_{50}\right)$ in $\mathrm{cm}$ for fish species and cuttlefish and mm for N. novergicus, and selection range (SR) for the main commercial species for sorting grids with 15 and 20 mm bar spacing (SG15 and SG20, respectively). AIC, Akaike information criterion.

\begin{tabular}{|c|c|c|c|c|c|c|c|c|}
\hline Species & Model & $\mathrm{a}$ & $\mathrm{b}$ & $\delta$ & $\mathrm{p}$ & $\mathrm{L}_{50}$ & SR & AIC \\
\hline & SG15 & & & & & & & \\
\hline & Logistic & -7.54 & 0.25 & & & 30.31 & 8.83 & 86.510 \\
\hline \multirow[t]{3}{*}{ N. norvegicus } & Richard & -9.72 & 0.30 & 1.56 & & 30.51 & 8.79 & 88.200 \\
\hline & Encounter probability & -9.78 & 0.31 & & 0.89 & 31.44 & 7.06 & 87,450 \\
\hline & Logistic & -4.83 & 0.33 & & & 14.56 & 6.62 & 355.96 \\
\hline \multirow[t]{3}{*}{ M. merluccius } & Richard & -0.32 & 0.28 & 0.04 & & 14.27 & 5.78 & 300.30 \\
\hline & Encounter probability & -4.83 & 0.33 & & 1.00 & 14.56 & 6.62 & 357.96 \\
\hline & Logistic & -2.90 & 0.22 & & & 13.14 & 9.95 & 147.96 \\
\hline \multirow[t]{3}{*}{ C. linguatula } & Richard & -5.35 & 0.30 & 2.21 & & 13.30 & 10.30 & 147.16 \\
\hline & Encounter probability & -4.14 & 0.28 & & 0.89 & 14.87 & 7.89 & 146.26 \\
\hline & Logistic & -2.84 & 0.40 & & & 7.160 & 5.56 & 96.580 \\
\hline \multirow[t]{4}{*}{ L. vulgaris } & Richard & 0.00 & 0.35 & 0.11 & & 7.280 & 4.60 & 92.030 \\
\hline & Encounter probability & -2.84 & 0.40 & & 1.00 & 7.160 & 5.56 & 98.570 \\
\hline & SG20 & & & & & & & \\
\hline & Logistic & -12.24 & 0.35 & & & 34.73 & 6.230 & 56.310 \\
\hline \multirow[t]{3}{*}{ N. norvegicus } & Richard & -7.68 & 0.26 & 0.33 & & 34.35 & 6.680 & 59.101 \\
\hline & Encounter probability & -12.24 & 0.35 & & 1.00 & 34.73 & 6.230 & 58.310 \\
\hline & Logistic & -3.96 & 0.29 & & & 13.46 & 7.470 & 575.72 \\
\hline \multirow[t]{3}{*}{ M. merluccius } & Richard & -28.33 & 1.27 & 15.22 & & 13.91 & 13.09 & 251.66 \\
\hline & Encounter probability & -16.69 & 0.87 & & 0.53 & 19.11 & 2.250 & 241.58 \\
\hline & Logistic & -4.55 & 0.28 & & & 16.53 & 7.983 & 112.33 \\
\hline \multirow[t]{3}{*}{ C. linguatula } & Richard & -7.28 & 0.38 & 1.91 & & 16.68 & 7.702 & 109.45 \\
\hline & Encounter probability & -5.31 & 0.31 & & 0.94 & 17.05 & 7.054 & 111.08 \\
\hline & Logistic & -3.22 & 0.32 & & & 9.952 & 6.780 & 84.830 \\
\hline \multirow{3}{*}{ L. vulgaris } & Richard & -4.09 & 0.35 & 1.48 & & 9.951 & 7.231 & 87.651 \\
\hline & Encounter probability & -3.22 & 0.32 & & 1.00 & 9.953 & 6.780 & 86.830 \\
\hline & Logistic & -2.95 & 0.46 & & & 6.352 & 4.732 & 91.381 \\
\hline \multirow{2}{*}{ S. officinalis } & Richard & 0.00 & 0.37 & 0.14 & & 6.181 & 4.430 & 97.023 \\
\hline & Encounter probability & -3.56 & 0.51 & & 0.88 & 6.962 & 4.292 & 92.441 \\
\hline
\end{tabular}


A)

N. norvegicus

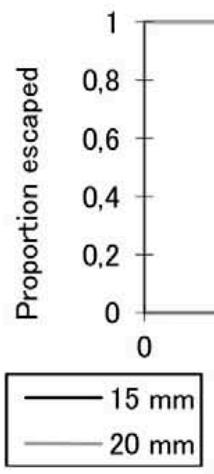

C)

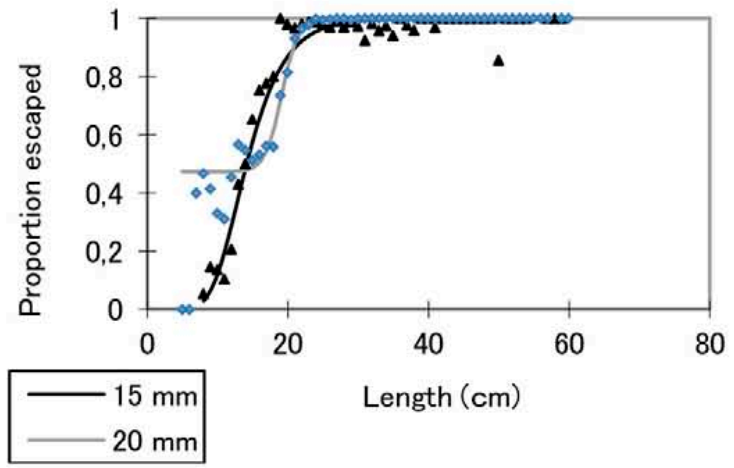

E)
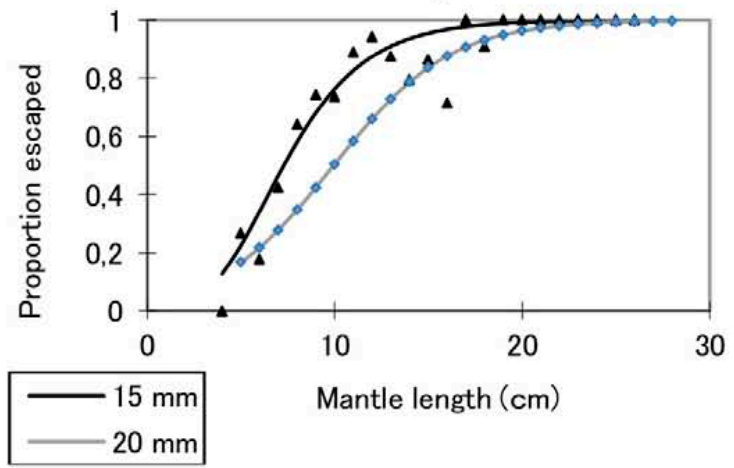

G)

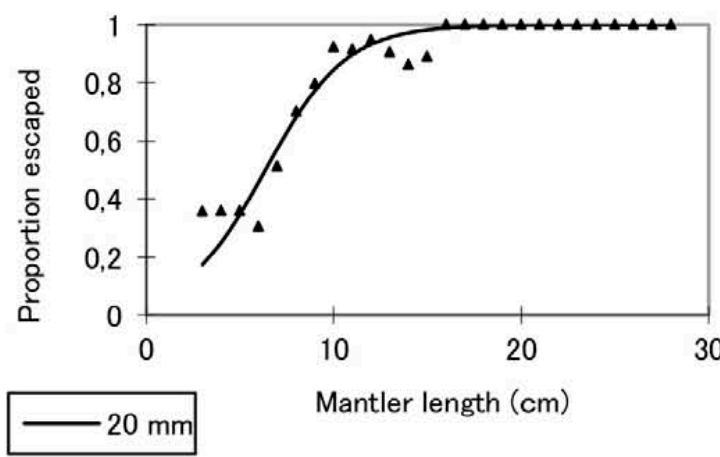

B)

C. linguatula

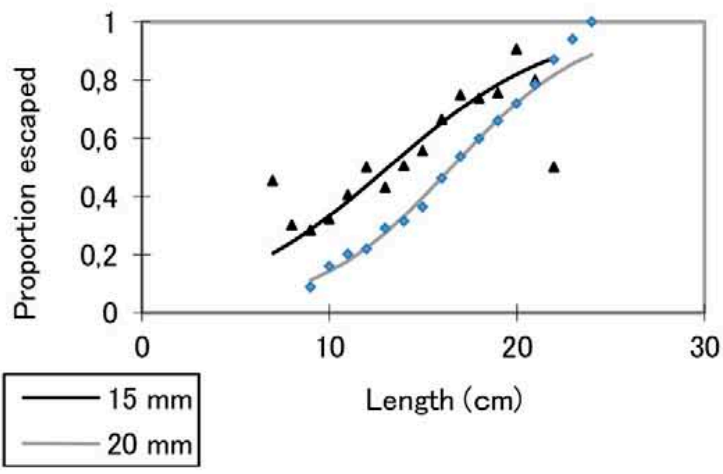

D)

M. merluccius

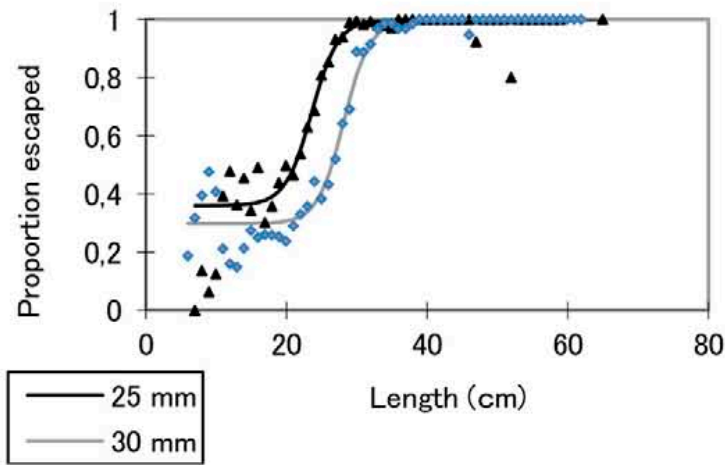

F)

L.vulgaris

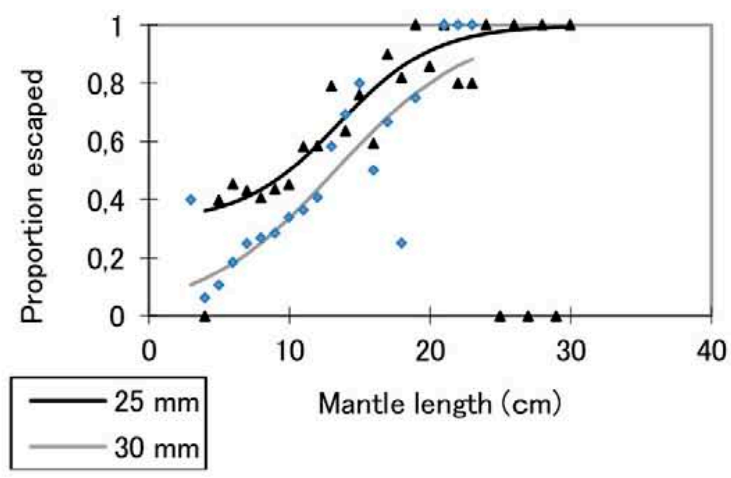

H)

S. officinalis

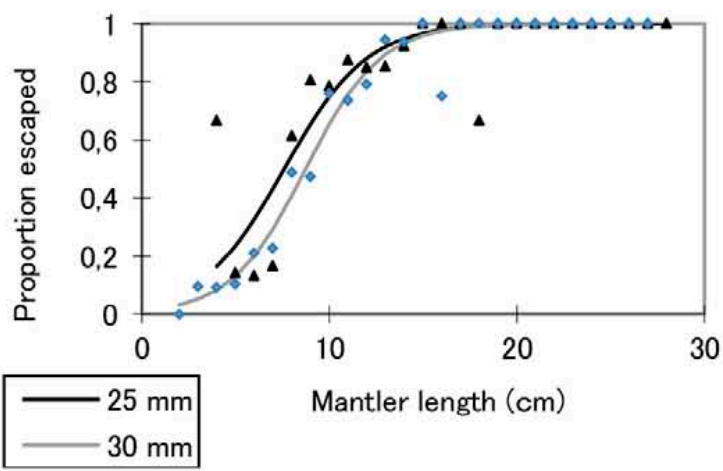

Fig. 7. - Selectivity curves for the main and by-catch species and for each bar spacing grid. 
Table 6. - Escape selection curve parameters (a. b. $\delta$ and p), length of $50 \%$ escapement $\left(\mathrm{L}_{50}\right)$ in $\mathrm{cm}$ for fish species and cuttlefish and mm for N. novergicus, and selection range (SR) for the main commercial species for sorting grids with 25- and 30-mm bar spacing (SG25 and SG30, respectively). AIC, Akaike information criterion.

\begin{tabular}{|c|c|c|c|c|c|c|c|c|}
\hline Species & Model & $\mathrm{a}$ & $\mathrm{b}$ & $\delta$ & $\mathrm{p}$ & $\mathrm{L}_{50}$ & SR & AIC \\
\hline \multirow{5}{*}{ M. merluccius } & SG25 & & & \multirow{5}{*}{8.49} & & & & \\
\hline & Logistic & -3.84 & 0.21 & & & 18.25 & 10.44 & 465.53 \\
\hline & Richard & -19.50 & 0.70 & & & 19.37 & 13.40 & 285.73 \\
\hline & Encounter probability & -12.51 & 0.53 & & 0.64 & 23.58 & 4.413 & 242.59 \\
\hline & Logistic & -1.51 & 0.16 & & & 9.513 & 13.87 & 127.83 \\
\hline \multirow{3}{*}{ L. vulgaris } & Richard & -1.83 & 0.16 & \multirow{2}{*}{1.21} & & 9.551 & 14.39 & 129.37 \\
\hline & Encounter probability & -3.96 & 0.29 & & 0.68 & 13.51 & 7.482 & 123.25 \\
\hline & Logistic & -3.43 & 0.45 & \multirow{3}{*}{0.35} & & 7.590 & 4.860 & 65.040 \\
\hline \multirow[t]{3}{*}{ S. officinalis } & Richard & -1.76 & 0.40 & & & 7.574 & 4.421 & 66.210 \\
\hline & $\begin{array}{l}\text { Encounter probability } \\
\text { SG30 }\end{array}$ & -3.43 & 0.45 & & 1.00 & 7.592 & 4.860 & 67.052 \\
\hline & Logistic & -1.98 & 0.09 & \multirow{4}{*}{25.43} & & 23.19 & 25.70 & 1188.18 \\
\hline \multirow[t]{3}{*}{ M. merluccius } & Richard & -50.07 & 1.36 & & & 23.82 & 20.52 & 877.19 \\
\hline & Encounter probability & -15.86 & 0.54 & & 0.70 & 28.17 & 4.080 & 466.40 \\
\hline & Logistic & -2.76 & 0.21 & & & 13.27 & 10.58 & 78.990 \\
\hline \multirow{3}{*}{ L. vulgaris } & Richard & 0.00 & 0.15 & \multirow[t]{2}{*}{0.19} & & 13.06 & 11.35 & 75.933 \\
\hline & Encounter probability & -2.75 & 0.20 & & 1.00 & 13.27 & 10.58 & 80.992 \\
\hline & Logistic & -4.41 & 0.50 & \multirow{3}{*}{1.01} & & 8.740 & 4.362 & 67.240 \\
\hline \multirow{2}{*}{ S. officinalis } & Richard & -4.49 & 0.51 & & & 8.771 & 4.301 & 69.281 \\
\hline & Encounter probability & -4.88 & 0.55 & & 0.97 & 8.900 & 4.011 & 68.591 \\
\hline
\end{tabular}

increased with increasing bar spacing, ranging from $35 \%$ to $73 \%$ for the 15 - and $30-\mathrm{mm}$ grids, respectively (Fig. 5E). The size ranges of fish retained in the codend ranged from 7 to $25 \mathrm{~cm}$ TL, with modal values of 11 to $17 \mathrm{~cm}$, depending on the grid bar spacing.

For squid, the size distributions in the codend and cover were all significantly different (Table 4). Selectivity curves were fitted (Fig. 7) with estimated $\mathrm{L}_{50}$ values of 7.28, 9.95, 13.51 and $13.06 \mathrm{~cm}$ ML for the 15-, 20-, 25- and 30-mm sorting grids, respectively (Tables 5 and 6). The sizes ranged from 4 to $21 \mathrm{~cm} \mathrm{ML,} \mathrm{with}$ modal values between 6 and $11 \mathrm{~cm} \mathrm{ML}$, depending on the bar spacing. The catch percentage varied between $19 \%$ and $61 \%$ (Fig. $5 \mathrm{H}$ ).

For cuttlefish, the size distributions showed a wide variation, from 3 to $16 \mathrm{~cm} \mathrm{ML,} \mathrm{with} \mathrm{a} \mathrm{modal} \mathrm{size} \mathrm{of} 7$ $\mathrm{cm}$ ML. According to the K-S test, cover and codend size distributions were significantly different for all grids except the 15-mm one (Table 4 ). The fitted selectivity curves for the 20-, 25- and 30-mm bar grids are shown in Figure 7. The estimated values of $\mathrm{L}_{50}$ were $6.35,7.59$ and $8.74 \mathrm{~cm} \mathrm{ML}$, respectively (Table 5 and $6)$. The catch percentages were low and they increased as the separation between the bars increased, ranging from $5 \%$ to $31 \%$ of retained cuttlefish for the 15 - and 30-mm grids, respectively (Fig. 5I).

\section{DISCUSSION}

The Gulf of Cadiz trawl fishery has a multispecies nature, with catch composition varying considerably with depth. There are, however, vessels targeting mostly deep-water rose shrimp throughout the year due to its high economic value in this area.

Encouraging results for the target crustacean species were obtained with the sorting grid device used for the first time in the Gulf of Cadiz. In particular, the $30-\mathrm{mm}$ grid showed high retention percentages, reducing the on-board sorting time and significantly improved the quality of the catches of Norway lobster, deep-water rose shrimp and prawn, two of which are very fragile species, with less crushing and damaged taking place, thanks to the considerably reduced catch biomass in the codend.

As the modified Nordmøre grid is designed to reduce the by-catch of finfish by facilitating the escape of large fish, its efficiency as a finfish fishing gear is very low, with only small sized individuals being retained. These results are in agreement with those of Isaksen et al. (1992), who evaluated the use of a sorting grid with a 19-mm separation between bars to reduce the fish bycatch in a shrimp trawl fishery. Indeed, the use of this device is compulsory by law in the Norwegian trawling fleet since 1990-1992.

For Norway lobster, the grids with the smallest separation ( 15 and $20 \mathrm{~mm}$ ) were the only ones with size selection. This finding could be due to the robust carapace and morphology of the species, which may prevent larger individuals from going through small bar spacing and allow them to escape towards the cover. The mean selection sizes $\left(\mathrm{L}_{50}\right)$ obtained were 30.31 and $34.73 \mathrm{~mm}$ CL for the 15 - and 20 -mm grids, respectively. However, escape percentages were high for the 15- and 20-mm sorting grids, varying between $86 \%$ and $42 \%$, respectively, which makes them not the most appropriate for this fishery. On the other hand, 25- and 30-mm sorting grids had lower escape percentages of $15 \%$ and $9 \%$, respectively, with a wide range of size captured.

European hake, regardless of bar spacing, had high escape percentages and consequently minimal codend catches. The maximum retention percentage $(29 \%$ of the total catch) was observed with the 30-mm bar spacing. The $\mathrm{L}_{50}$ estimates were 14.12, 19.1, 23.75 and $28.18 \mathrm{~cm}$ for the $15-, 20-, 25-$ and $30-\mathrm{mm}$ grids. All of the sorting grids tested allowed capture of hakes under $27 \mathrm{~cm}$ TL (the MLS for this species in the Gulf of Cadiz) in the codend. However, this is not a serious problem since deep-water rose shrimp and Norway lobster are caught at depths where individuals of hake smaller than $27 \mathrm{~cm}$ are not found under normal circumstances in this area (Sobrino et al. 1993). Small European 
Table 7. - Total number and weight percentage of hake specimens below the minimum legal size $(27 \mathrm{~cm})$ during the survey.

\begin{tabular}{ccc}
\hline Depth range $(\mathrm{m})$ & Number & Weight percentage \% \\
\hline$<100$ & 10201 & 35.81 \\
$100-200$ & 11852 & 45.61 \\
$200-300$ & 4149 & 14.57 \\
$300-400$ & 1677 & 5.89 \\
$400-500$ & 360 & 1.26 \\
$500-600$ & 224 & 0.79 \\
$>600$ & 20 & 0.07 \\
\hline
\end{tabular}

hake are found at depths of less than $100 \mathrm{~m}$, moving towards greater depths (200-400 m) only after sexual maturity is achieved (Anonymous 2005). Nonetheless, since their catch rates are fairly low (Table 7), the use of these sorting grids, which considerably reduce the catch of other non-target species, is still recommended.

For spotted flounder, escape percentages appeared to be the same regardless of the bar spacing of the grids (Fig. 6). This could be related to the morphology of the species, with the flattened body facilitating passage through any bar spacing. Selectivity parameters could only be estimated for the 15- and 20-mm bar spacing grids with $\mathrm{L}_{50}$ of 14.87 and $16.68 \mathrm{~cm}$, respectively (Table 5). It is perhaps interesting from the fishermen's point of view since this species does not have an MLS in the Gulf of Cadiz, and they would continue landing spotted flounder, which is a species of medium economic value

When choosing the ideal spacing between the bars of the grid, a compromise must be reached between reducing the catch of undersized demersal species and promoting the escape of non-target species, while retaining most of the commercially valuable crustacean species. Isaksen et al. (1992) obtained encouraging results for the shrimp fishery in Norway, where the $19 \mathrm{~mm}$ bar spacing only reduced shrimp catch by $5 \%$ compared with control hauls (with no sorting device) and achieved a reduction in the by-catch for several different species.

The results of this study show that the sorting grid with a $30-\mathrm{mm}$ bar spacing is the most suitable for deployment on-board the commercial trawlers of the Gulf of Cadiz, since it will reduce the by-catch of the species under study by $59 \%$, while only reducing the catches of prawn, deep-water rose shrimp and Norway lobster by $14 \%, 8 \%$ and $9 \%$, respectively. These values could be acceptable for the fishing fleet if we also take into account the positive effects on product quality. Furthermore, unlike the other grids with narrower bar spacing, there was no significant difference in escapement with increasing tow duration and depth for the $30-\mathrm{mm}$ grid.

According to the majority of authors (Campos and Fonseca 2003, Campos et al. 2003, Sardà et al. 2006), it is difficult to apply management methods in multispecies fisheries where catches consist of many commercial species. If such regulatory measures were taken in order to improve fishery management in the Gulf of Cadiz, it would be advisable to split the fishing licences and mitigation measures into two groups: one for the trawlers fishing for crustaceans in deeper waters using a sorting grid and a 55-mm mesh size, and a different one for boats mainly fishing for finfish and cephalo- pods, which would use a different device and have a bigger mesh size, as is recommended by the EU. In Sweden the use of a grid when trawling for Nephrops has been mandatory since 2004. This fishery is now a single-species fishery where Nephrops constitutes $94 \%$ of the landings (Valentinsson and Ulmestrand 2005).

In a multispecies fishery, with interest in keeping legally sized commercial fish species, it is likely that a short-term economic impact will follow, and some form of incentive may be required to implement effective measures. If fishers cannot be convinced of the medium and long-term conservation and economic benefits of more selective fishing, and be persuaded to voluntarily adopt new measures, then direct economic incentives would be required (Catchpole and Revill 2007). This type of approach, adopting different measures and agreements for each type of licence, could be acceptable to the commercial trawling fleet in the Gulf of Cadiz, reducing the overharvesting of demersal resources and contributing to a more sustainable multispecies fishery.

Considering the above, our proposal for this fishery would be to implement this device in the part of the fleet targeting crustaceans. Taking advantage of the current situation of the fleet, with severe reductions in the allowable catches of target species such as $\mathrm{Ne}$ phrops norvegicus, high fuel costs and reductions in fishing hours, we propose that vessels using the device voluntarily be offered incentives and opportunities such as a larger share of the TAC, increased fishing times according to species distribution and availability and a minimum market price for the product. Furthermore, with the recent EU regulation regarding a 'landing obligation' for discards, attempts should be made, through collaboration with fishermen and skippers, to find solutions for the discards resulting from this fishery. Meetings with the fleet representatives will be necessary for the future success of implementation of this device.

\section{ACKNOWLEDGEMENTS}

The authors would like to thank the crews of the fishing vessels for their hard work and skills, as well as all of their colleagues at the Instituto Español de Oceanografía who took part in the survey.

\section{REFERENCES}

Anonymous. 2005. Estudio de los parámetros biológicos (crecimiento y reproducción) de diversas especies de interés pesquero en aguas del Golfo de Cádiz y Sur-Mediterráneo. Consejería de Agricultura y Pesca, Junta de Andalucía Inf. Cient.

Akaike H. 1974. A new look at the statistical model identification. IEEE Trans. Autom. Contr. AC-19: 716-722. http://dx.doi.org/10.1109/TAC.1974.1100705

Broadhurst M. K. 2000. Modifications to reduce by-catch in prawn trawls: A review and framework for development. Rev. Fish. Biol. Fish. 10: 27-60. http://dx.doi.org/10.1023/A:1008936820089

Campos A., Fonseca P. 2003. Selectivity of diamond and square mesh cod ends for horse mackerel (Trachurus trachurus), European hake (Merluccius merluccius) and axillary seabream (Pagellus acarne) in the shallow groundfish assemblage off the south west coast of Portugal. Sci. Mar. 67: 249-260. http://dx.doi.org/10.3989/scimar.2003.67n2249 
Campos A., Fonseca P., Erzini K. 2003. Size selectivity of diamond and square mesh cod ends for four by-catch species in the crustacean fishery off the Portuguese south coast. Fish. Res. 60: 79-97 http://dx.doi.org/10.1016/S0165-7836(02)00061-9

Catchpole T.L, Revill A.S. 2007. Gear technology in Nephrops trawl fisheries. Rev. Fish. Biol. Fish. 18 (1): 17-31 http://dx.doi.org/10.1007/s11160-007-9061-y

Coll M., Carreras M., Cornax M.J., et al. 2014. Closer to reality: Reconstructing total removals in mixed fisheries from Southern Europe. Fish. Res. 154: 179-194. http://dx.doi.org/10.1016/j.fishres.2014.01.013

Ercoli R., Izzo A., Salvini L., et al. 2001. Experiencias de selectividad en los copos de las redes de arrastre y desarrollo de dispositivos selectivos con grillas en la pesquería argentina. El Mar Argentino y sus recursos pesqueros. INIDEP Doc. Cient. 3: 121-478.

Fonseca P., Campos A., Larsen R.B., et al. 2005. Using a modified Nordmore grid for by-catch reduction in the Portuguese crustacean trawl fishery. Fish. Res. 71: 223-239. http://dx.doi.org/10.1016/j.fishres.2004.08.018

González-Garcés A., Pereiro F.J. 1994. Present stage of knowledge of hake populations which live on the continental shelf of the Atlantic and Mediterranean parts of the European Union, with especial attention to the Iberian Peninsula. Private publication. Instituto Español de Oceanografía. pp. 327.

Isaksen B. 1990. Grid sorting system to reduce by-catch of fish in shrimp trawl. ICES Fish. Tec. 8.

Isaksen B., Valdemarsen J.W., Larsen R.B., et al. 1992. Reduction of fish by-catch in shrimp trawl using a rigid separator grid in the aft belly. Fish. Res. 13: 335-352. http://dx.doi.org/10.1016/0165-7836(92)90086-9

Jiménez M.P., Sobrino I., Ramos F. 2004. Objective methods for defining mixed-species trawl fisheries in Spanish water of the Gulf of Cádiz. Fish. Res. 67: 195-206. http://dx.doi.org/10.1016/j.fishres.2003.09.048

Ramos F., Sobrino I., Jiménez M.P. 1997. Cartografiado temática de los caladeros de la flota de arrastre en el Golfo de Cádiz. Dirección general de investigación y formación agraria. Servicio de publicaciones y divulgación. Junta de Andalucía. 84-87564-96-8.

Sardà F., Bahamón N., Molí B., et al. 2006. The use of a square mesh codend and sorting grids to reduce catches of young fish and improve sustainability in a multispecies bottom crawl fishery in the Mediterranean. Sci. Mar. 70(3): 347-353. http://dx.doi.org/10.3989/scimar.2006.70n3347

Sobrino I. 1998. Biología y pesca de la gamba blanca (Parapenaeus longirostris, Lucas 1846) en el Atlántico nororiental. Ph.D. thesis. Univ. Sevilla. Spain: 218 pp.

Sobrino I., García T. 2007. Reproductive aspects of the deep-water rose shrimp Parapenaeus longirostris (Lucas,1846) in the Gulf of Cadiz (southwestern Iberian Peninsula). Bol. Inst. Esp. Oceanogr. 23(1-4): 57-71.

Sobrino I., Jiménez M.P., Ramos F. 1993. Resultados preliminares sobre la distribución y abundancia de la merluza europea (Merluccius merluccius L.) en la región suratlántica española. En: González-Garcés A., Pereiro F.J. Estado actual de los conocimientos de las poblaciones de merluza que habitan la plataforma continental atlántica y mediterránea de la Unión Europea con especial atención a la Península Ibérica. Vigo : Instituto Español de Oceanografía, pp. 281-304.

Sobrino I., Jiménez M.P., Ramos F., et al. 1994. Descripción de las pesquerías demersales de la Región Suratlántica Española. Inf. Tec. Inst. Oceanog. 151.

Sobrino I., Ramos F., Jiménez M.P., et al. 1996. Study on the Spanish trawling fleet components and mapping of resources exploited by this fleet off the Gulf of Cadiz. Final Report.Cooperative Project No. IEO/EC-DG XIV/C/1/STUDY/94/029.

Tokai T. 1997. Maximum likelihood parameter estimates of a mesh selectivity logistic model through SOLVER on MS-Excel. Bull. Jpn. Soc. Fish. Oceanogr. 61 (3): 288-298.

Tokai T., Omoto S., Sato R., et al. 1996. A method of determining selectivity curve of separator grid. Fish. Res. 27: 51-60. http://dx.doi.org/10.1016/0165-7836(95)00471-8

Valdermarsen J.W., Lehmann K., Riget F., et al. 1993. Grid devices to select shrimp size in trawls. ICES Stat. Meet. Fish. capt. Comm. CM 1993/B35.

Valentinsson D., Ulmestrand M. 2005. Mandatory use of speciesselective grids in the Swedish Nephrops trawl fishery on national waters-Experiences after one year with new regulations. Inst. Mar. Res. Rep. Sweden, Lysekil.

Wileman D.A., Ferro R.S.T., Fonteyne R., et al. 1996 Manual of methods of measuring the selectivity of towed fishing gear. ICES Coop. Res. Rep. 215. 